20. Honcharenko V. V. Kredytna kooperatsiia. Forma ekonomichnoi samodopomohy silskoho i miskoho naselennia u sviti ta v Ukraini (teoriia, metodolohiia, praktyka): monograph. Kyiv: Hlobus, 1998. 330 p.

21. Koltunova Yu. I. Sotsial'nye aspekty sel'skokhozyaystvennoy kooperatsii: proceedings // Kooperatsiya i integratsiya v APK na rubezhe XX-XXI vekav. Tyumen', 1998. P. 117-120.

22. Zinovchuk V. V. Orhanizatsiini osnovy silskohospodarskoho kooperatyvu. Kyiv: Lohos, 2001. 380 p.

\section{ИССЛЕДОВАНИЕ КООПЕРАЦИИ В АГРОБИЗНЕСЕ КАК} СОЦИАЛЬНО-ЭКОНОМИЧЕСКОГО ЯВЛЕНИЯ

Проведен анализ методологических подходов к пониманию сущности кооперации. Подается новый концептуальный подход к пониманию кооперации, который определяет, что по содержанию - кооперация является экономическим явлением, а по организационной форме - кооператив. Обоснованно формирование и функционирование кооператива на основе проявления внутренних и внешних отношений, носителями и регуляторами которых кооперативные принципы.

Kлючевые слова: кооперация в агробизнесе, производственные отношения, кооперативные принципы, внутренние и внешние отношения.
Horbonos Fedir, Doctor of Economic Sciences, Professor, Rector, Lviv University of Business and Law,Ukraine, e-mail: fhorbonos@ukr.net, ORCID: http://orcid.org/0000-0002-6563-9847

Pavlenchyk Nataliya, Doctor of Economic Sciences, Associate Professor, Head of the Department of Economics, Management, Hotel and Restaurant Business, Lviv State University of Physical Culture, Ukraine, e-mail: pavlinova75@gmail.com,ORCID: http://orcid.org/ 0000-0001-6164-5644

Pavlenchyk Anatolii, PhD, Associate Professor, Department of Economics, Management, Hotel and Restaurant Business, Lviv State University of Physical Culture, Ukraine, e-mail: pavlenchyk@bigmir.net, ORCID: http://orcid.org/0000-0002-2205-1883

Skrynkovskyy Ruslan, PhD, Associate Professor, Department of Business Economy and Information Technology, Lviv University of Business and Law, Ukraine, e-mail: uan_lviv@ukr.net, ORCID: http://orcid.org/0000-0002-2180-8055

\section{Kolodizieva T., Kotsiuba 0.}

\title{
IMPLEMANTATION OF WORLD EXPERIENCE IN CREDIT PROGRAMS OF DEVELOPMENT OF LOGISTICS INFRASTRUCTURE, LOGISTICS SYSTEMS AND TECHNOLOGIES
}

Розглянуто основні тенденщї фінансування програм розвитку логістичної інфраструктури провідних країн світу. Проаналізовано міжнародний досвід кредитування програм розвитку об'єктів логістичної інфраструктури на прикладі таких країн, як Філіппіни, США, Індія та Болгарія. Виділено основні організаційні аспекти фінансування логістичної інфраструктури, які доцільно використати в українській практиці і визначати конкурентні переваги розвитку економіки.

Ключові слова: транспортна інфраструктура, логістична система, кредитні програми, фiнансування кредитних програм, смарт-міста.

\section{Introduction}

The modern state of economic system of Ukraine, subsequent development of market partnership and quite difficult consequences of running a business urge national enterprises to:

- search for measures for income increase;

- decrease of total costs;

- reduction of time periods between raw materials buying and selling out the production to the customers, and also to ways of supporting the positive image of the company.

During the recent years it is common for these aims to use creating effective logistics infrastructure. It can much improve enterprise`s indicators and create continuous chain of financial flows management. The results of structural analysis of effective development of world companies show that during the production cycle only $2 \%$ of time is spent for production, other $98 \%$ are connected directly or indirectly with products astir. Generally, expenses on products astir are more than $15 \%$ of the gross national product [1]. It proves significance on the stage of search for mechanisms and sources of effective logistics system funding in the country is the basis of economic growth. The necessity of modernization of transport system in Ukraine and the search for alternative funding ways prove the relevance of the research of implementation of the world experience.

\section{The object of research and its technological audit}

The object of research is the process of logistics infrastructure development programs crediting. 
In order to create a stable and effective functioning logistics infrastructure in Ukraine there was implemented the international experience of crediting and financing programs of transport development. The most developing logistics systems are in such countries as Philippines and India. Government of Philippines has invested more than 140 bln.USD for the past 7 years. India is focusing on rebuilding its town into smart-cities. And this fact attracts a lot of investors from Spain, France, Japan and other countries. So, it is essential to analyze this positive experience and consider it while development of its implementation measures in Ukraine.

\section{The aim and objectives of research}

The aim of the study is analysis of world experience of implementation credit programs of development of logistics infrastructure.

In order to achieve the aim it is necessary to solve following problems:

1. To analyze the state of realization of Ukrainian logistics infrastructure development projects and to determine the source of its financing.

2. To analyze world experience of logistics infrastructure development projects crediting.

3. To determine main steps in searching for financing sources and implementation logistics infrastructure development projects.

\section{Research of existing solutions of the problem}

Research of lending and financing logistics infrastructure development programs is engaged by many scholars and practitioners. Thus, studies [1-3] consider aspects of Ukraine's integration into the transport and logistics system of the European Union. An overview of the main financial schemes that can be used to finance innovative programs is given in the work [4]. Publications [5-7] provide an overview of the mechanisms for forecasting the need for additional funding for logistics infrastructure. The works [8-10] present the results of cooperation of Ukrainian agro-industrial companies with foreign investors for the realization of logistics infrastructure development programs. Reports on the state of development of the main objects of development of Ukraine's transport infrastructure are presented in works [11-13]. The Official Website of the Philippine Development Bank [14] provides a detailed description of lending programs for state-owned logistics infrastructure projects. American experts [15-17] review US state-owned coastal ports infrastructure financing practices. The prospects and the state of development of Indian logistics infrastructure are presented in [18]. The Bulgarian State Logistics Infrastructure Strategic Development Program presents an overview of the main areas and facilities that will need funding in 2020-2024, as well as the list and requests from potential lenders [19].

\section{Methods of research}

To solve posed problems there were used following methods: analysis and synthesis, logical generalization, analogies, comparisons, graphical analysis.

\section{Research results}

Generalizing of the world companies experience shows that expenses for product astir are divided in the following way:

$46 \%$ - transport by main lines among regions;

$26 \%$ - move to warehouses;

$7 \%$ - keeping on the necessary level of products reserves;

$6 \%$ - operations of loading and receiving goods;

$4 \%$ - packing;

$3 \%$ - processing orders. Transport and international activities of economic institutes are strongly connected and influence significantly on each other.

It is expedient to consider existing competitors' advantages in the aspect that geographical location of Ukraine as a transit country and widening of international trade play special role for transport services of international activity. But for all that transport is considered as elements of macrologistics systems of international trade.

There are:

- 33 airports;

- 20 state trade sea-ports;

- 8 river-ports;

- 6 railways;

- more than 90 avia- and 150 ship-companies;

- more than 75 thousands of enterprises, which owe autos, in Ukraine [20].

The state of logistics system of Ukraine is unsatisfying, which is proved by the World Bank's research. It states that Ukraine has 102 place in the rate of logistics efficiency among 155 countries. Evaluation was held according to the following criteria: efficiency of the custom-house control, infrastructure of transport logistics, access and easiness of international deliveries organization. In the structure of Ukrainian logistics market transport takes $89 \%$, delivery ranges management $-1 \%$, expeditions $2 \%$, storage $-8 \%$ [4].

Ukraine plays a significant role in the logistics projects in Europe, which is connected with advantageous geographical position. It is proved by the high transit rate among European countries of British institute Rendell 3.75 points. There are following participant trends of Ukraine in European transport and logistics integration:

- European transport corridors;

- Transcontinental transport corridors;

- European transport zones;

- International logistics terminals.

There is also a range of functioning investment projects in Ukraine, which are aimed at the development of logistics infrastructure. Therefore, in December 2016 it was signed a contract between company «NIBULON» (Mykolaiv, Ukraine) and European Investment Bank (EIB) about the funding of investment program in order to develop and modernize logistics infrastructure of Ukraine. It is important to admit that investments were granted without government guarantees, but just under the liabilities of Ukrainian companies [8].

Credit sources in amount of 71 million EUR, which was granted by EIB, allow to raise 200 million USD investment portfolio of the company. Investments are funding project of «NIBULON» company, which will be seen fulfilled in the nearest 2-3 years - «Development and reconstruction of elevators (building and providing of seed storage companies), building transshipping and logistics terminal (building towboats) in Ukraine». 
The project is aimed at creating of stable, modern and wider seed storage and transport system, as a result of that it is considered to decrease of prices on internal shipping and increase of annual export amount of agricultural products. The results of the projects realization are implementation of more resource-saving internal shipping as there will be implemented replacement of automobiles by river transport by the mean of building a system of river terminals all over the country.

In the context of the program «NIBULON» company is going to:

- build up to 10 modern elevator complexes, including on Dnipro and Southern Bug, what allows to increase the amount of the seed storage to $2.5 \mathrm{mln}$. tons;

- reconstruct shipyard «NIBULON», which gives an opportunity to build up to 15 ships and machine up to 15000 tons of metal a year;

- increase deadweight of its cargo fleet up to 250000 tons; - increase of inland water transporting (Dnipro and Southern Bug) up 4 million tons, which allows to safe 3.16 billion UAH of governmental sources on ways repairs [8].

The world logistics market is not only characterized by large amounts and dynamics (12\% of gross world product), but also geographical structure. In this case West Europe $(27.5 \%)$ and North America $(26.7 \%)$ are leaders.

Other project, which «NIBULON» company is realizing, is aimed to widen and optimize logistics of float of grain, increasing of grain trade results, decreasing of use of car and rail ships [9]. The project will be realized in Mykolajiv region - building of river ports and reconstruction of existing ports in the region. On January $19^{\text {th }}$ in 2018 Board of directors of the European investment bank has signed an agreement to credit 50 million USD to the «NIBULON» company for the realization of the named project. The application complies with social and ecological policies of the Bank. It played a significant role while making a decision [10].

The development of urban transport system is rapidly increasing in Ukraine. 2 projects of building new underground lines in Kiev and Kharkiv were resolved by foreign investors in 2017. It means that international partners consider Ukraine as strategic partner and support projects, which are aimed to improve the infrastructure of the key cities.

On January $22^{\text {th }} 2017$ the agreement between Kyiv City State Administration and Chinese consortium China Pacific Construction Group for crediting of 1.7 billion USD to Ukraine for building a new $18 \mathrm{~km}$ underground line. The credit was received under the state guarantees [11]. This project will be a significant contribution to development of Ukrainian-Chinese relationship. Now there are negotiating about building a free trade zone between Ukraine and China. That will make easier admission and functioning for Chinese manufacturers and traders to the Ukrainian market.

The Minister of Finance of Ukraine has signed an agreement with European Bank for Reconstruction and Development and European Investment Bank about receiving 320 million USD for building 2 underground stations in Kharkiv. The credit term is 18 years and the interest rate is $0.01 \%$ form the loaned sum [12].

There is one more project, which is aimed to develop transport infrastructure of Ukrainian regions in order to optimize trade and agriculture. European Bank for Reconstruction and Development credits 150 million USD for electrification the railway line in the South of Ukraine. The aim is improvement of connection between port and internal regions of the country. The total investments needed are 367.9 million EUR. The rest of the sum will be brought from the governmental budget [13].

The results of the systematization existing projects according to different ways and economic fields prove that logistic infrastructure is developing in 3 key ways: urban, agricultural and transport. Urban projects are aimed to building new extra underground lines. Agricultural projects are aimed to build additional and sufficient transport lines, granaries etc. Transport projects are aimed to improve existing transport lines, electrification distant regions etc. The generalized graphic scheme is shown on the Fig. 1.

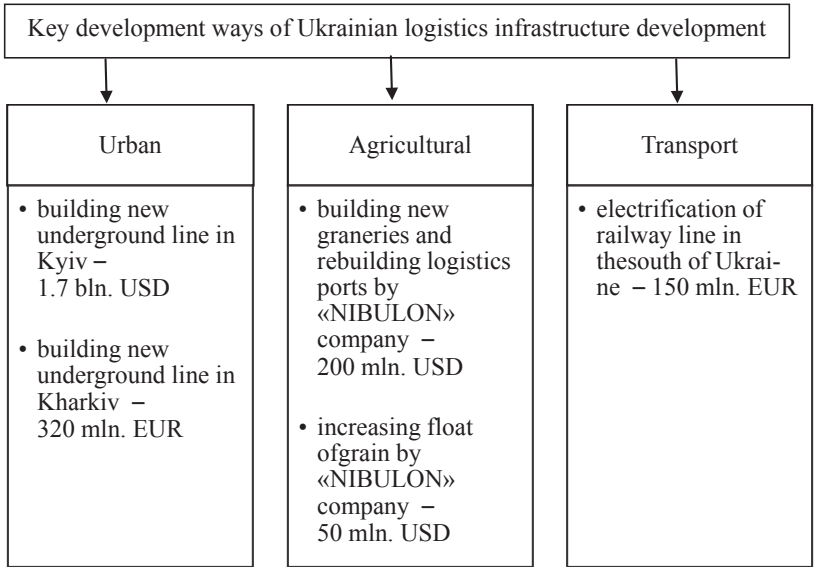

Fig. 1. Generalized scheme of projects, which are aimed to develop Ukrainian logistics infrastructure as of 01.01.2018

One of the examples of implementation of credit programs of logistics infrastructure is the program of Development Bank of Philippines. As an archipelago of over 7,000 islands, the Philippines requires efficient and modern transport infrastructures, logistics facilities and power infrastructures to accelerate and sustain its socio-economic growth, improve its global competitiveness, and promote physical integration.

DBP addresses this need through its Connecting Rural Urban Intermodal Systems Efficiency (CRUISE) Program. This umbrella program aims to support investments that improve the country's primary transport infrastructure and logistics facilities. It will contribute to provide affordable, reliable and safe mass transport systems; support the efficient movement of basic commodities; bring down the costs of goods and services; and introduce sustainable storage, handling and distribution technologies [13].

The CRUISE program employs long-term funds from various sources including Official Development Assistance funds such as the Logistics Infrastructure Development Project from the Japan International Cooperation Agency. In Fig. 2 it is indicated the main credit sectors according to the CRUISE program.

Development Bank of Philippines supports governmental initiatives in building integrating and modern national transport and logistical system, according to the Development Plan of Philippines for 2011-2016. Main options of credit programs are listed in Table 1. 


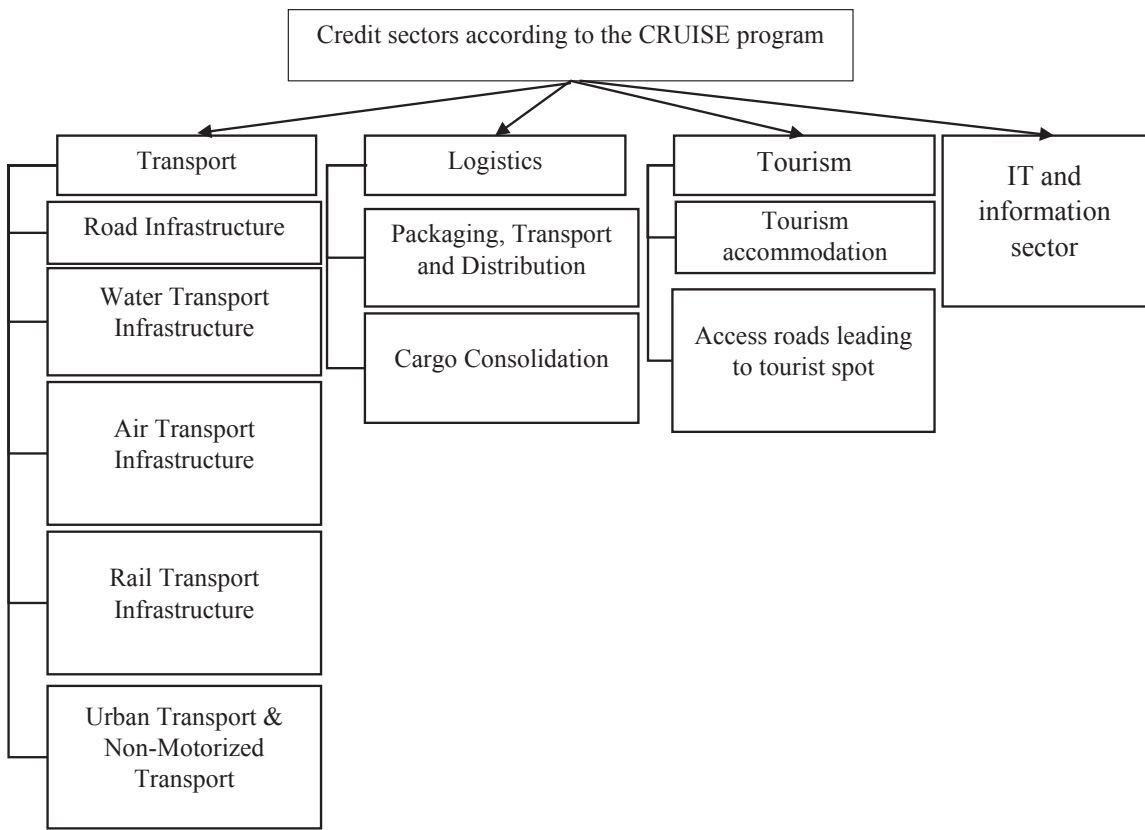

Fig. 2. Main credit sectors according to the CRUISE program [14] undertakings of corruption overcoming, Philippines economy is increasing sharply.

In the USA the most popular are programs of port infrastructure development. Such projects are government initiative and nongovernmental investments amount $35-50 \%$. But in recent years government doesn `t participate actively in funding of such programs. In the end of 2016 it was implemented 17 programs of water infrastructure development, 8 out of 17 are in an active phase of implementation in 11 states. The general amount of investments comes to 5.2 billion USD. In Fig. 3 it is indicated the weight of governmental funding sources of funding logistics infrastructure projects [16].

The USA has implemented different funding mechanisms. Florida state has the biggest amount of financial resources.

Table 1

Main options of credit programs in Development Bank of Philippines*

\begin{tabular}{|l|l|}
\hline \multicolumn{1}{|c|}{ Options } & \multicolumn{1}{c|}{ Characteristics } \\
\hline Borrowers & $\begin{array}{l}\text { - companies and corporations; } \\
\text { - local government; } \\
\text { - national corporations and companies; } \\
\text { - governmental agencies (where allowed); } \\
\text { - copperatives and associations; } \\
\text { - Participating Financial Institutions and Microfinance } \\
\text { Institutions. }\end{array}$ \\
\hline Interest Rate & Prevailing market rate (fixed or variable) \\
\hline Repayment Terms & $\begin{array}{l}\text { Up to maximum 15 years inclusive of up to } 5 \text { years } \\
\text { grace period based on project cash flows }\end{array}$ \\
\hline Loan Amount & $\begin{array}{l}\text { For private corporations, enterprises, cooperatives } \\
\text { and associations - up to 80 \% of total project cost } \\
\text { For governmental corporations, companies - up to } \\
\text { g0 \% total project cost }\end{array}$ \\
\hline
\end{tabular}

Note: ${ }^{*}$ data was taken from $[14,21]$.

The result of implementation of the CRUISE Program in Philippines it was considered the start of «golden era» of transport system in 2017, according to Transport Ministry of Philippines.

Therefore, considerable investments in transport infrastructure stimulated off economic growth, renewing of contacts with neighbor countries and improvement of contacts between archipelago islands. The government invested in transport structure of the country 140 billion USD for 2011-2016, 41.3 billion USD including was received by the government and companies as the credit of Development Bank of Philippines.

It is important to admit, that Philippines has just begun to develop logistics infrastructure. The length of railways was only $70 \mathrm{~km}$, ports weren`t even connected with each other by roads. According to the Secretary of Transport Department Arthur P. Tugade, the development of transport system was disturbed by the significant level of corruption on the top-management [21]. After some
Therefore, it is used:

- incomes from oil and gas sells;

- general government incomes;

- Trust Funds of Transport Ministry;

- local budgets;

- government bonds.

To fund some logistics program government increases tax rates and tax basis. Such method was used for funding Texas Port TRZ.

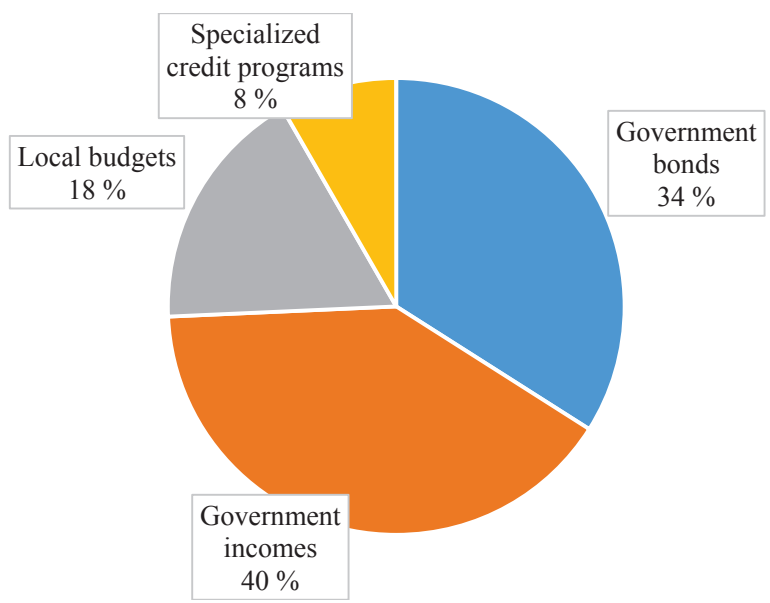

Fig. 3. Governmental funding of logistics infrastructure programs in the USA in the first half of 2015 [16]

Logistics infrastructure is the key element of Indian economy. This infrastructure sector is the basis of general economic development of India. The Minister of Transport Nitin Hadkari expressed an opinion in May 2017, that the government has set up a goal to invest 376.53 billion USD in development of logistics infrastructure in the nearest 3 years [17].

The total investment amount for $2017-2022$ is 454.83 billion USD, $70 \%$ are aimed at funding of logistics infrastructure projects [22]. 
Interest in India has been quickened by international companies in the infrastructure sector. Many Spanish companies are ready to cooperate and are doing it now with Indian organizations in the sphere of high-speed trains' production and development of smart-cities, etc. The main investors are:

- Abertis Infrastructuras SA, Spanish manufacture company, agreed to buy 2 elevators form Macquarie Group (Southern India) for 151 billion USD;

- GVK Power \& Infrastructure Ltd (India) was decided on tender successful in the sphere of building of the second airport in Mumbai for 2.39 billion USD;

- skyTran Inc. (USA), NASA partner is specialized on lorries production for cities and plans to build specialized highway in India;

- Silver Spring Capital Management (China), hedge funds, head-office in Hong-Kong, is going to invest more than 306 million USD in highways building;

- Altico Capital (India), non-banking financial institution of Clearwater Capital Partners LLC plans to invest about 150 million USD in infrastructure of a city in the nearest 12-18 months;

- Global Pension Funds is going to invest up to 50 billion USD in logistics infrastructure of India;

- Development Bank of Asia and Indian government signed an agreement about a loan for 80 million USD, which is the third tranche for the total amount of 200 million USD in the context of Investment programs of urban development of North-Eastern region; - France means business to invest 2.17 billion USD in reconstruction of 3 cities in smart-cities in India. Indian port system will count $943.06 \mathrm{~km}$ to the Indian main ports and $815.20 \mathrm{~km}$ to secondary port in the end of 2017. Indian aviation market can become the third biggest in the world in 2020. There is a possible opportunity of hosting 336 million local and 85 million international passengers with the rough investments 120 billion USD. It is considered, that Indian aviation infrastructure count $1.5 \%$ of GNP of India and is a tool of future economic growth of the country. The Ambassador of Japan believes, government of Japan is interested in the urbanistic development of India and has decided to cooperate with 3 smart-cities of India (Chennai, Ahmedabad, Varanasi).

There is a transport system development program in Bulgaria for 2014-2020 - Operational Program under the Investment for Growth and Jobs`Goal «Transport and Transport Infrastructure» [19].

According to the aims of the Program the following parameters of the national transport system should be improved: characteristics of the transport network, existing capacity - physical and operational structure of the network and volumes. They can be achieved depending on demand of transport services, as well as operation condition of the network and ability to provide reliable and safe transport services.

Investments will be concentrated mainly on completion of priority railway and road directions and promotion of multimodal transport - construction of intermodal terminals and improvement of ports and airports connections to the road and railway network. A better integration of the national transport network into EU transport network and improved connections with neighbouring countries will be achieved gradually completing the modernization of the sections of Trans-European [19].

Bulgarian transport model updated in 2013 (part of the General Transport Master Plan), identifies main sections of the road and railway network. It is expected major traffic increase until 2020 and 2030 and sections where demand forecast is close to or above existing capacity. In Table 2 it is presented an overview of the investment strategy of operational program.

The analysis of the dynamic of indicators of the logistics programs realization may draw a conclusion that transport system is developing with a high speed in the world. The quality of roads, railways, ports and airports characterize the general economic development of the country and its readiness ad willingness to cooperate with international partners. The data about foreign experience of implementation of transport development projects is generalized in the Table 3 .

Overview of the investment strategy of the operational program in Bulgaria*

\begin{tabular}{|c|c|c|c|c|}
\hline No. & Fund & $\begin{array}{c}\text { Union Support, } \\
\text { million EUR }\end{array}$ & $\begin{array}{l}\text { Proportion of total Union support } \\
\text { for the operational program }\end{array}$ & Thematic objective \\
\hline 1 & Cohesion Fund & 572.344 & $35.67 \%$ & $\begin{array}{l}\text { - supporting a multi-model Single European Transport Area; } \\
\text { - increasing railway traffic of passenger and freight through improving the } \\
\text { quality of the railway infrastructure }\end{array}$ \\
\hline 2 & Cohesion Fund & 572.344 & $35.67 \%$ & $\begin{array}{l}\text { - supporting a multi-model Single European Transport Area; } \\
\text { - increasing railway traffic of passenger and freight through improving the } \\
\text { quality of the railway infrastructure }\end{array}$ \\
\hline 3 & $\begin{array}{l}\text { European } \mathrm{Re}- \\
\text { gional Develop- } \\
\text { ment Fund }\end{array}$ & 361.300 & $22.52 \%$ & $\begin{array}{l}\text { - promoting low-carbon strategies for all types of territories, in particular } \\
\text { for urban areas, including the promotion of sustainable multimodal urban } \\
\text { mobility and mitigation-relevant adaptation measures; } \\
\text { - increased use of metra; } \\
\text { - increased intermodal transport }\end{array}$ \\
\hline 4 & $\begin{array}{l}\text { European } \\
\text { Regional Deve- } \\
\text { lopment Fund }\end{array}$ & 57.944 & $3.61 \%$ & $\begin{array}{l}\text { - improved transport management through introduction of innovative systems; } \\
\text { - developing and rehabilitating comprehensive, high quality and interoperable } \\
\text { railway systems, and promoting noise-reduction measures; } \\
\text { - improved management of the railway network }\end{array}$ \\
\hline 5 & $\begin{array}{l}\text { European } \\
\text { Regional Deve- } \\
\text { lopment Fund }\end{array}$ & 40.517 & $2.53 \%$ & $\begin{array}{l}\text { - establishment of necessary conditions for successful completion of the } \\
\text { program 2007-2013 and implementation of the program 2014-2020, } \\
\text { strengthening the administrative capacity and public awareness of the program }\end{array}$ \\
\hline
\end{tabular}

Note: ${ }^{*}$ data was taken from [19]. 
Table 3

Perspectives of implementation of world experience in the sphere of logistics infrastructure development, logistics systems and technologies in Ukraine*

\begin{tabular}{|c|c|c|c|c|c|}
\hline \multirow{2}{*}{ Country } & \multicolumn{3}{|c|}{$\begin{array}{c}\text { Transport development, logistics systems and } \\
\text { technologies projects }\end{array}$} & \multicolumn{2}{|c|}{$\begin{array}{l}\text { Perspectives of implementation of world } \\
\text { experience in Ukraine }\end{array}$} \\
\hline & $\begin{array}{l}\text { Name } \\
\text { of the program }\end{array}$ & $\begin{array}{l}\text { Expected } \\
\text { results }\end{array}$ & $\begin{array}{l}\text { Amounts and } \\
\text { investment sources }\end{array}$ & $\begin{array}{l}\text { Contents and } \\
\text { courses }\end{array}$ & $\begin{array}{l}\text { Investment } \\
\text { sources }\end{array}$ \\
\hline Philippines & CRUISE & $\begin{array}{l}\text { - renewing of contacts } \\
\text { with neighbor countries; } \\
\text { - improvement between } \\
\text { archipelago islands }\end{array}$ & $\begin{array}{l}\text { - credits of Development } \\
\text { Bank of Philippines; } \\
\text { - governmental sources }\end{array}$ & $\begin{array}{l}\text { - improving of roads leading to tou- } \\
\text { rism spots, including development of } \\
\text { touristic infrastructure and ancient } \\
\text { landmarks; } \\
\text { - improving road infrastructure quality }\end{array}$ & $\begin{array}{l}\text { Credits to local } \\
\text { budgets }\end{array}$ \\
\hline U5A & $\begin{array}{l}\text { Texas Port TRZ (and } \\
\text { other same program } \\
\text { in } 10 \text { states) }\end{array}$ & $\begin{array}{l}\text { - acquisition of con- } \\
\text { tainer cranes or other } \\
\text { mechanized equipment } \\
\text { used in the movement of } \\
\text { cargo or passengers in } \\
\text { international commerce }\end{array}$ & $\begin{array}{l}\text { - specialized credit рго- } \\
\text { grams; } \\
\text { - government bonds; } \\
\text { - local budgets; } \\
\text { - government incomes }\end{array}$ & $\begin{array}{l}\text { - construction or improvement of } \\
\text { wharves, docks, structures, jetties, } \\
\text { piers, storage facilities, cruise termi- } \\
\text { nals, or any facilities necessary or } \\
\text { useful in connection with maritime port } \\
\text { transportation or economic development }\end{array}$ & $\begin{array}{l}\text { - government } \\
\text { incomes }\end{array}$ \\
\hline India & - & $\begin{array}{l}\text { - widening of range of } \\
\text { airports; } \\
\text { - building highways; } \\
\text { - urban development; } \\
\text { - reconstruction } 3 \text { cities } \\
\text { into smart-cities }\end{array}$ & $\begin{array}{l}\text { - Spanish investors; } \\
\text { - Global Pension Funds; } \\
\text { - Development Bank of } \\
\text { Asia; } \\
\text { - Indian government }\end{array}$ & $\begin{array}{l}\text { - reconstruction of cities into smart- } \\
\text { cities; } \\
\text { - highways buildings }\end{array}$ & $\begin{array}{l}\text { - investments of } \\
\text { private companies; } \\
\text { - Government } \\
\text { sources }\end{array}$ \\
\hline Bulgaria & $\begin{array}{l}\text { Operational program } \\
\text { under the Investment for } \\
\text { Growth and Jobs' Goal } \\
\text { «Transport and Transport } \\
\text { Infrastructure» }\end{array}$ & $\begin{array}{l}\text { - increasing railway traf- } \\
\text { fic and railway infra- } \\
\text { structure; } \\
\text { - promoting low-carbon } \\
\text { strategies }\end{array}$ & $\begin{array}{l}\text { - European Union Funds; } \\
\text { - investments of Bulgar- } \\
\text { ian and other companies; } \\
\text { - governmental costs }\end{array}$ & $\begin{array}{l}\text { - improving management of railway } \\
\text { network; } \\
\text { - increasing intermodal transport }\end{array}$ & $\begin{array}{l}\text { - investment of } \\
\text { companies; } \\
\text { - governmental } \\
\text { sources }\end{array}$ \\
\hline
\end{tabular}

Note: ${ }^{*}$ built by author.

The Fig. 4 shows the amount of credit resources which are assigned to financing of logistics infrastructure projects.

Research of realization features of the financing development programs of logistics infrastructure of the European countries and all over the world proves perspectives of their implementation. But it may be considered some disadvantages. The biggest one is that the programs are being funded by governmental sources. This definition is general and there are no details about possible ways of increasing government incomes. The information about funding these projects by private or foreign investors is also doubtful, because there aren`t any commerce aspects in renewing roads. In Ukrainian conditions to find large amount of financial sources is extremely difficult, because there aren`t many investors, which would like to invest in transport systems and roads renewing and in economic at all. Governmental sources aren`t enough now even to stop economical declining and the high level of corruption inhibits governmental financing of logistics infrastructure programs.

On the other hand, to take in account of world experience for Ukraine is needed, because of low level of roads quality in some central regions, not large number of highways and absence of smartcities. Improving transport system will help Ukraine to improve its international contacts.

In order to activate lending processes for logistics infrastructure projects in Ukraine, it is important to have transparent results of the analysis of the state of logistics infrastructure, programs of development of regions of the country and knowledge of international experience in the field of development of transport systems of the state. The signing of credit agreements is based on agreements between Ukraine and the European Union, investment strategies for the development of the European Union and strategies for the development of Ukrainian logistics companies [5, 15].

This information is necessary to understand the further vector of the development of logistics infrastructure in terms of global and Ukrainian regional trends, in particular. The entities that can lend to the objects of logistic infrastructure are state and local authorities, international funds, banks, private investors. The analysts contribute to a reliable analysis of the state of the country's logistics infrastructure, the formation of consolidated results of the efficiency of the use of financial resources, the identification of possible additional reserves for improving the efficiency of projects and adapting the foreign experience of lending to the objects of the transport system. This generalized information is presented in the form of a context diagram depicted in Fig. 5.

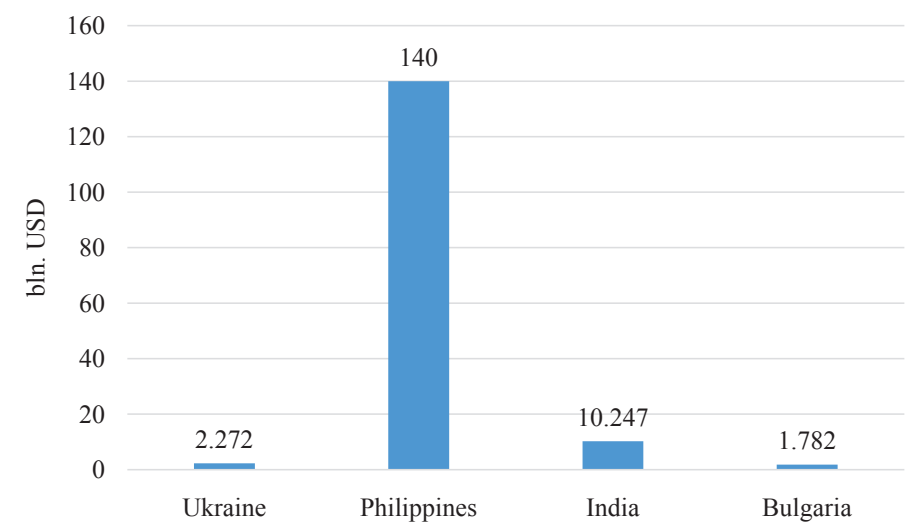

Fig. 4. Amount of credit resources, which are needed for financing logistics infrastructure development projects of some world countries from 2017 to 2022 


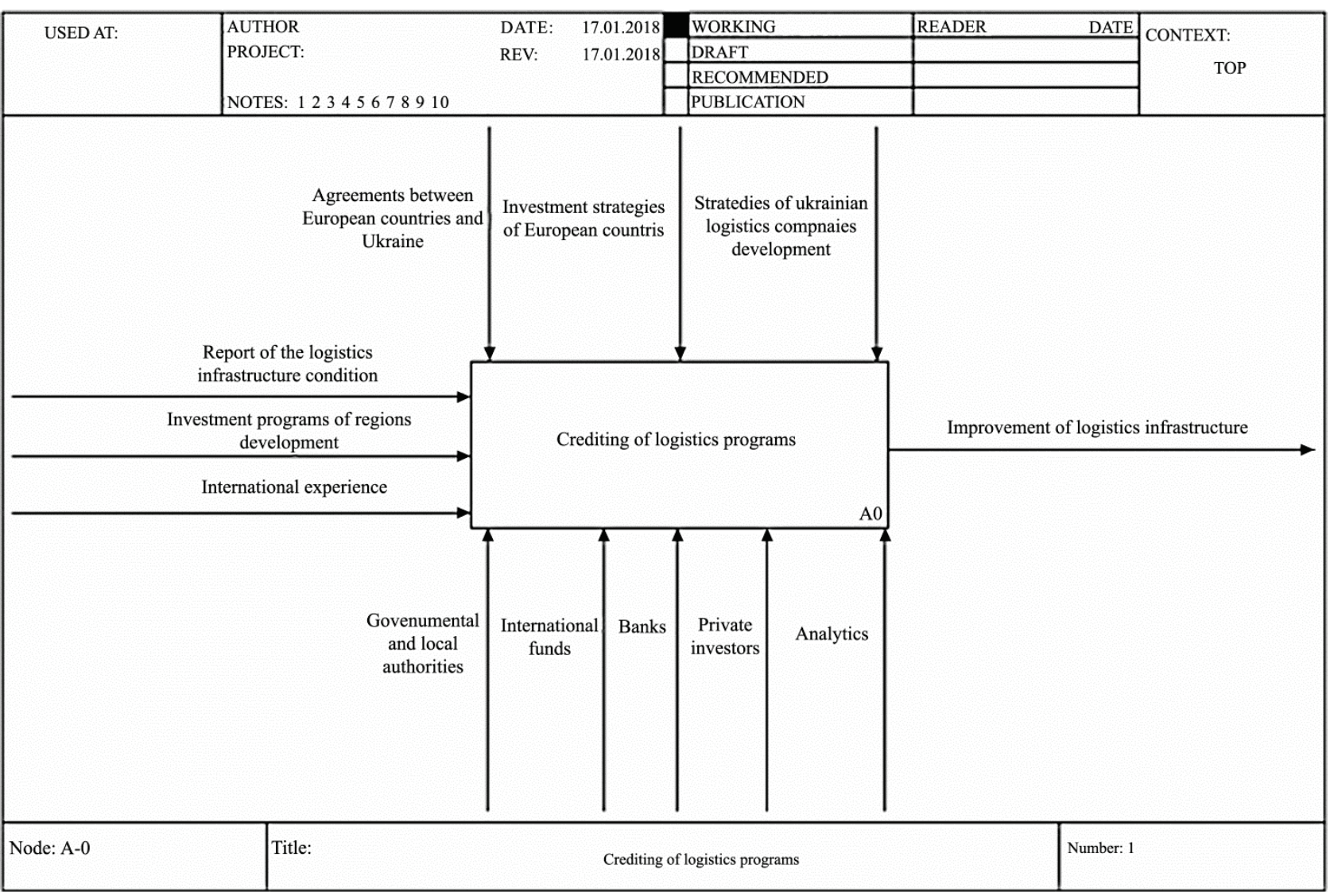

Fig. 5. Context diagram of the process of lending logistics infrastructure programs

The implementation of these tasks is appropriate to the use of specific methods of research and systematization of analytical material. In order to ensure efficient management of the implementation of credit programs for the development of logistics infrastructure, it is advisable to build a management model that would allow a more detailed analysis of the structure of financing processes and further concentrate efforts on overcoming bottlenecks.

One of the most commonly used simulation methods today is the structurally functional method that allows to set the elements needed to perform the functions of a particular system and to identify the appropriate interactions between them.

The structural functional model is based on using the CASE-method in the ERwin Process Modeler software product according to the IDEF0 standard, which provides a description of the steps of the simulated process.

The decomposition of the context diagram involves the implementation of 4 steps (Fig. 6):

1. Analysis of logistics infrastructure objects.

2. Creating necessary conditions for attracting investors and creditors.

3. Implementation of organizational instruments of determination and researching for concealed reserves for financing logistics development

4. Realization of programs of development of logistic infrastructure.

For the effective implementation of the first stage, the incoming information is reports on the state of the logistics infrastructure of Ukraine and the world as a whole. The subject is analyst, and the methodological recom- mendations will become strategies for the development of domestic logistics companies. The source information will be a report on the amount of funding required for logistics infrastructure.

Creating the necessary conditions for attracting investors and creditors requires the following input information investment programs of the regions of Ukraine (for understanding the vector of development of the domestic economy and industry) and international experience (for using the most effective methods of attracting financial resources). Governmental and local authorities, as well as international funds, carry out this stage. Incoming information will be the reports on the required amount of financing of the objects of logistic infrastructure and the Agreements between the European Union and Ukraine.

On the basis of these Agreements it is possible to predict the probability of obtaining the necessary funding from international funds, including depending on the investment interests of the countries of the European Union and other world countries. The result of this stage will be the creation of the necessary laws to regulate the investment activity of the country.

The next step is searching and attracting investors and lenders. Inputs should include investment development programs for the regions of the state, as well as a report on the state of the logistics infrastructure. The search for investors and creditors can be done by state and local authorities. When improving the quality of roads, rebuilding cities on smart cities, or upgrading villages and settlements, investors and lenders may require government guarantees, which determine the role of the state in these processes. 


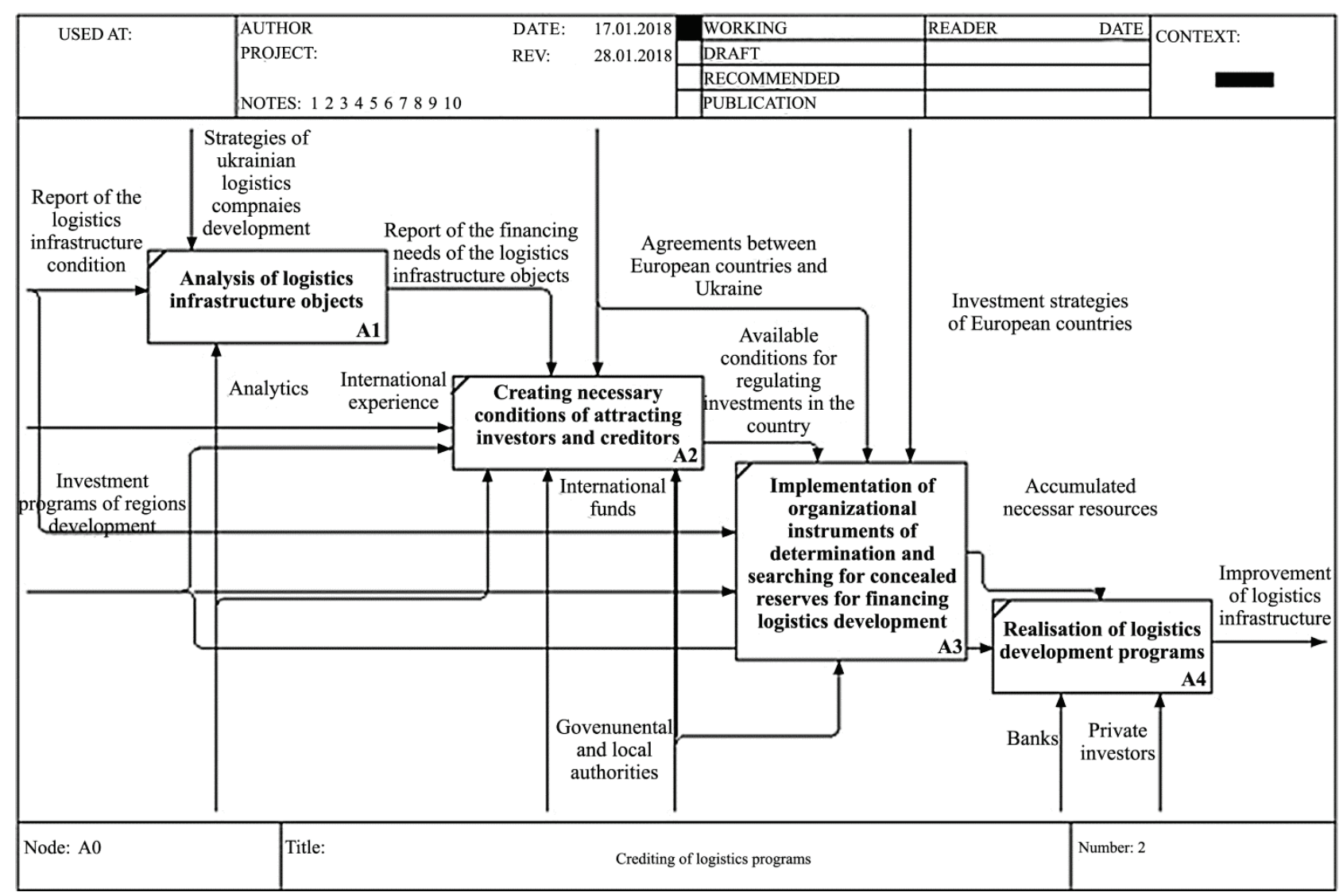

Fig. 6. Chart of the decomposition of the process of lending logistic infrastructure programs

The initial information of the stage will be accumulated financial resources necessary for the implementation of programs for the development of logistics infrastructure.

The last stage of improving the logistics infrastructure the implementation of investment programs - is based on regional investment programs and business plans for the development of logistics facilities. Logistics companies, banks and private investors will deal directly with the implementation.

Application of CASE-method in Erwin Process Modeler software according to IDEF0 standard allowed:

- to present the process of crediting development programs of logistic infrastructure;

- logically to structure it;

- to reveal from the large array of qualitative and quantitative aspects phenomena the most significant and observe intermediate results.

\section{SWOT analysis of research results}

Strengths. The strength of the study is analysis the global experience of lending and investing in logistics infrastructure and systems; a detailed overview of the prospects for the development of logistics infrastructure of world countries.

Weaknesses. The weakness is the insufficient review of the mechanisms for attracting investment and credit resources for the implementation of logistics infrastructure development projects in line with world experience.

Opportunities. Opportunities for using the results of further research can be considered the introduction of foreign experience in lending to projects of logistics infrastructure of the country.

Threats. The risks of implementing the results of the carried out research is that the development of logistics infrastructure requires significant financial and material resources, but most projects do not represent commercial value for investors and creditors. Therefore, the main burden lies with the state and local authorities, which at the moment are not able to fully meet their obligations in full in the short term of the projects.

\section{Conclusions}

1. Based on the analysis of actual reports on the state of financing and implementation of objects of development of Ukrainian logistics infrastructure, in particular, it was concluded that there is a high interest to Ukraine from foreign investors. At the same time, however, there is a low level of lending by Ukrainian or foreign banks to such projects due to low profitability.

2. The international experience of lending programs for the development of logistic infrastructure in the Philippines, USA, India, and Bulgaria has been analyzed. Based on the results of the study, it can be argued that Ukraine should implement overseas experience in implementing such projects.

3. The synthesis of international experience has allowed to build a structural and functional model of the process of logistics infrastructure programs crediting using the CASE-method in the ERwin Process Modeler software product under the standard IDEF0. This model allows to 
set the elements, the steps needed to perform the functions of a certain system and to identify the appropriate interactions between them.

\section{References}

1. Malovychko A. S. Integration of Ukraine into the Transport and Logistics System of the European Union // Black Sea Economic Studios, 2016. Vol. 7. P. 141-148.

2. Gutsal I. S., Strutynska I. V. Crediting of Investment projects of Logistics Centers Creating // Effective economy. 2011 No. 11. URL: http://www.economy.nayka.com.ua/?op $=1 \& z=767$

3. Poliakova O. M., Shramenko O. V. Modern trends of development of transport and logistic infrastructure in Ukraine and the world // Journal of Transport and Industry. 2017. No. 58 P. 126-134. doi:10.18664/338.47:338.45.v0i58.110015

4. Christophersen H., Bodewig K., Secchi C. Action Plan: Making the best use of new financial schemes // European Commission. June 2015. 38 p. URL: https://ec.europa.eu/transport/ sites/transport/files/themes/infrastructure/ten-t-guidelines/doc/ 2015_06_03_cbs_action_plan_final.pdf

5. Bayane B. M., Yanjun Q. Transport infrastructure development in China // Journal of Sustainable Development of Transport and Logistics. 2017. Vol. 2, No. 1. P. 29-39. doi:10.14254/ jsdtl.2017.2-1.3

6. Zuraimi A. A., Yaacob M. R., Ibrahim M. D. Logistics Development in Malaysia East Coast Region: Infrastructure, Constraints and Challenges // International Journal of Trade, Economics and Finance. 2013. Vol. 4, No. 5. P. 325-330. doi:10.7763/ ijtef.2013.v4.310

7. The impact of transport infrastructure projects on sustainable development within a major logistics gateway in North West England / Paraskevadakis D. et al. // Logistics \& Sustainable Transport. 2016. Vol. 7, No. 1. P. 28-40. doi:10.1515/ jlst-2016-0003

8. European Investment Bank invests $71 \mathrm{mln}$. EUR for realization of the «NIBULON» company // NIBULON.com. December 20, 2016. URL: http://www.nibulon.com/news/novini-kompanii/ evropeiskii-investiciinii-bank-vidilyae-71-mln-evro-na-realizaciyuinvesticiinoi-programi-kompanii-nibulon.html

9. Agribusiness «NIBULON» expects to receive a loan of USD 4-50 million from the EBRD for a loan // Kfund-media.com November 9, 2017. URL: https://kfund-media.com/ru/agrokorporatsyya-nybulon-rasschytyvaet-na-40-50-mln-kredyta-ot-ebrr/

10. The EBRD approved a decision to grant a loan in the amount of USD 50 million to NIBULON Company // NIBULON. com. January 19, 2018. URL: http://nibulon.com/news/novini-kompanii/ebrr-uxvaliv-rishennya-pro-nadannya-kompanii-nibulon-kreditu-na-sumu-50-mln-dolariv-ssha.html

11. The fourth branch of the metro in Kiev will be built by a Chinese consortium // Kfund-media.com. November 22, 2017. URL: https://kfund-media.com/ru/chetvertuyu-vetku-metro-vkyeve-budet-stroyt-kytajskyj-konsortsyum/

12. Ukraine has signed an agreement to inflate an additional 320 million euros for the completion of the metro in Kharkiv // Kfund-media.com. December 11, 2017. URL: https://kfundmedia.com/ru/ukrayna-zaklyuchyla-soglashenyya-o-pryvlechenyye320-mln-na-dostrojku-metro-v-harkove/

13. UZ Railways agreed with the EBRD on obtaining a loan for modernization of the railway // Biz.nv.ua. December 14 2017. URL: https://biz.nv.ua/markets/ukrzaliznytsja-dogovorilas-o-kredite-na-modernizatsiju-zheleznoj-dorogi-2369411.html
14. Development Bank of Philippine // Devbnkphl.com. URL https://www.devbnkphl.com/

15. Angelucci M. Conditional Cash Transfer Programs, Credit Constraints, and Migration // LABOUR. 2011. Vol. 26, No. 1. P. 124-136. doi:10.1111/j.1467-9914.2011.00534.x

16. Kruse C. J. Survey of State Funding Practices for Coastal Port Infrastructure // Static.tti.tamu.edu. May, 2015. URL: https://static.tti.tamu.edu/tti.tamu.edu/documents/PRC-15-51-F.pdf

17. Gupta R., Mehta H., Netzer T. Transforming the nations logistics infrastructure // Mckisev.com. September, 2010. URL: http:// www.mckinsey.com/industries/travel-transport-and-logistics/ our-insights/transforming-indias-logistics-infrastructure

18. Ramachandran N., Rajandran K. V. R. Logistics Management and Challenges of Infrastructure Development- An Operational Approach of A University // Indian Journal of Applied Research. 2011. Vol. 4, No. 4. P. 1-4. doi:10.15373/2249555x/ apr2014/250

19. Operational Programme «Transport and Transport Infrastructure» (2014-2020) // Eufunds.bg. October 8, 2015. URL: https://www. eufunds.bg/index.php/en/programming-period-2014-2020/operational-programmes-2014-2020/operational-programme-transportand-transport-infrastructure-2014-2020/item/13782-operational -programme-transport-and-transport-infrastructure-2014-2020

20. Official site of the State Statistics Committee of Ukraine. URL: http://ukrstat.gov.ua/

21. Philippines entering 'golden age for logistics infrastructure' // Lloydsloadinglist.com. 3 March 2017. URL: http://www. lloydsloadinglist.com/freight-directory/news/Philippinesentering-\%E2\%80\%98golden-age-for-logistics-infrastructure\% E2\%80\%99/68737.htm\#WYHiDulLfIV

22. World Bank Web-site // Worldbank.org. URL: http://worldbank.org/

\section{ВНЕДРЕНИЕ МИРОВОГО ОПЫТА КРЕДИТОВАНИЯ РАЗВИТИЯ ЛОГИСТИЧЕСКОЙ ИНФРАСТРУКТУРЫ, ЛОГИСТИЧЕСКИХ СИСТЕМ И ТЕХНОЛОГИй}

Рассмотрены основные тенденции финансирования программ развития логистической инфраструктуры ведущих стран мира. Проанализирован международный опыт кредитования программ развития объектов логистической инфраструктуры на примере таких стран, как Филиппины, США, Индия и Болгария. Выделены основные организационные аспекты финансирования логистической инфраструктуры, которые целесообразно использованы в украинской практике и определять конкурентные преимущества развития экономики.

Ключевые слова: транспортная инфраструктура, логистическая система, кредитные программы, финансирование кредитных программ, смарт-города.

Kolodizieva Tetiana, PhD, Associate Professor, Department Economics, Enterprise Management and Logistics, Simon Kuznets Kharkiv National University of Economics, Ukraine, ORCID: http://orcid.org/ 0000-0001-6247-7179, e-mail: Kolodizeva@ukr.net

Kotsiuba Olena, Department of Banking, Simon Kuznets Kharkic National University of Economics, Ukraine, ORCID: http://orcid.org/ 0000-0003-1365-1788, e-mail: kotsiubaelena@gmail.com 